Check for updates

Cite this: RSC Adv., 2017, 7, 45920

\title{
Evidencing the diversity and needs of adjustment of the nutritional requirements for hydrocarbon- degrading activity of Pseudomonas aeruginosa adapted to harsh conditions using $2^{n}$ full factorial design
}

\author{
Al Zahraa Attar, $\uparrow$ Samir Jaoua, $\$$ Talaat A. Ahmed,§ Zulfa Al Disi (iD 9 \\ and Nabil Zouari $\dot{I}^{*}$
}

To overcome the partial or complete failure of oil hydrocarbon bioremediation due to weathering processes, occurring in most oil producing and spilling areas, nutritional requirements of the most widely used bacterium, Pseudomonas aeruginosa, were shown to be necessary to predict in advance, because they affect its activity to remove categories of polluting hydrocarbons. This study showed a high diversity of the relationship between the metabolism and the biological activity of Pseudomonas aeruginosa. The Gulf area represents a good site to isolate three highly adapted Pseudomonas aeruginosa strains from different highly polluted and weathered soils. The close relationship between the bacterial strains and the micro environment composition was investigated. Statistical analysis, using $2^{3}$ factorial design, of the correlation between nutritional requirements of three Pseudomonas aeruginosa strains and their potential to degrade diesel hydrocarbons was carriedout. Long term adaptation of hydrocarbon-degrading bacteria to weathered hydrocarbons and harsh conditions provides them with specific metabolic potentialities that vary from one isolate to another although belonging to the same species. The sensitivity of hydrocarbon-degrading bacterial growth and the biological activity of the three isolates were analyzed. The optimal media composition in term of carbon, nitrogen and phosphorous concentrations related to their C/N/P ratios varied among the isolates with a maximal biomass production reaching $90 \times 10^{7} \mathrm{CFU} \mathrm{m}{ }^{-1}$. The significance of the first and second order interactions of $\mathrm{C}, \mathrm{N}$ and $\mathrm{P}$ sources showed high variability in the impact on growth and biological activity. Hydrocarbon removal was much higher for high molecular weight ones, reaching almost $90 \%$ for strains under specific growth conditions for each isolate. This is of high importance for remediating weathered oil. Mostly, all strains expressed enhanced removal activity by the second week of incubation. However, removal and conversion of diesel hydrocarbons was found to be highly sensitive to the availability and balance of the nutrients and varied from one Pseudomonas aeruginosa strain to another. This is of great importance from the practical point of view for spilled oil bioremediation using Pseudomonas aeruginosa.

Received 26th April 2017 Accepted 20th September 2017

DOI: $10.1039 / \mathrm{c} 7 \mathrm{ra0} 4704 \mathrm{e}$ rsc.li/rsc-advances attractive option to reduce pressure on the environment. ${ }^{\mathbf{1}}$ Soil microorganisms are able to obtain energy by implementing appropriate metabolic pathways to oxidize soil pollutants such as hydrocarbons, ${ }^{2}$ providing detoxification of the environment. ${ }^{3}$ Bacteria develop metabolic pathways to ensure high capabilities of hydrocarbon biodegradation. One of them is chemotaxis which is a system of signalling, allowing the cells to have access to hydrocarbons by sensing high concentrations of the hydrocarbons. ${ }^{4-6}$ Cells accumulate between the pollutants which are hydrophobic and the aqueous medium, resulting in increasing the rate of their desorption and thus degradation. ${ }^{7}$ Some bacteria are able to adsorb to pollutants rich particles through their hydrophobic wall, and form biofilms. ${ }^{8,9}$ Others produce surfactants having the ability to increase the solubility of hydrophobic compounds and to improve accessibility. ${ }^{\mathbf{1 0}}$ Then, 
bacteria use degradation products which are more hydrophilic as carbon sources. ${ }^{11}$ In addition, the physical and chemical characteristics of soils as well as weather conditions, affect the chemical stability of the pollutants and their availability to biodegradation. While exposed to the environment, petroleum products can change through photodegradation, oxidation, partitioning, biodegradation, and volatilization, further making it difficult to examine the risk of exposure. These weathering processes are more accentuated in arid climate, such as in Gulf area. Each polluted area is characterized by a set of biotic and abiotic factors which guide to select the strategy of bioremediation of the corresponding pollutants. Therefore, there is need for further studies as a way of characterizing the populations of the hydrocarbons-degrading bacteria as well as their potential in the metabolic activities, especially at harsh conditions. Microorganisms namely Burkholderia, Arthrobacter, Pseudomonas, Mycobacterium, Rhodococcus, and Sphingomonas were found to be involved in the process of alkylaromatic degradation. Recently, Nwinyi et al. discovered microbial degradation of petroleum hydrocarbons in the highly polluted tropical ecosystems. ${ }^{12}$ The highest capability of degrading crude oil was attributed to Acinetobacter lwoffi, Pseudomonas fluorescens, Pseudomonas aeruginosa, Alcaligenes sp., Bacillus sp., Bacillus subtilis, Corynebacterium sp., and Micrococcus roseus. Several bacterial isolates have received particular attention in terms of their biodegradation potential. Pseudomonas aeuroginosa (P. aeuroginosa) is, so far, the most studied hydrocarbon-degrading bacterium. In fact, the metabolic diversity of hydrocarbondegrading bacteria is the origin of success of bacterial processes.

The aim of the present study is to explore the effect of long term adaptation of hydrocarbon-degrading $P$. aeruginosa strains to weathered hydrocarbons at harsh conditions and their specific metabolic potentialities. Isolation of three strains of $P$. aeruginosa was performed according to an isolation strategy of hydrocarbondegrading bacteria from weathered soils as previously showed. ${ }^{\mathbf{1 3 , 1 4}}$ A factorial experimental design was applied to investigate the correlation between growth parameters and hydrocarbon-degradation activity. The chosen model was Linear additive model for a Completely Randomized Design (CRD). Indeed, separate control of each technological process parameter is not enough for success of approaches of weathered oil bioremediation, but much focus should be laid on physiological parameters. This should be important from the practical point of view in any bioaugmentation processes for oil-hydrocarbons remediation. A set of biotic and abiotic factors in each polluted area should guide and orient the biodegradability of the corresponding pollutants. In fact, this represents the main origin of failure of most of bioaugmentation and/or biostimulation applications for cleaning polluted areas with hydrocarbons using intrinsic bacteria. Insights should be provided into the metabolic diversity of those bacteria. Here, study of the biological diversity adds to a better demonstration of diversity even within the same species of bacteria, $P$. aeruginosa, a well-known hydrocarbondegrading bacterium. Factor analysis is a useful tool to investigate the relationships in complex microbial systems. The novelty of this work is to demonstrate for the first time by using the factorial analysis that each strain of $P$. aeruginosa adapts differently the metabolism of hydrocarbons as a response to variable medium compositions. Here, the response to the combined factors was doubly observed by growth and tolerance to toxicity as well as degradation of three ranges of hydrocarbons specified by their molecular weights in raw diesel, which increased the complexity of the system and the originality of the study. It allowed to investigate the two concepts which are not easily evaluated directly by collapsing the other variables into a few interpretable underlying factors. The system comprised the most influencing nutritional requirements which are carbon, nitrogen and phosphorous and their interactions was studied using $2^{n}$ factorial design. To ensure such an evidence, adapted bacteria to harsh conditions were isolated and used. The implementation of such an approach would lead to identify the most appropriate conditions for success of bioaugmentation and/or biostimulation applications. This would lead to overcome most of oil bioremediation failure reasons related to the appropriate implementation of $P$. aeruginosa.

\section{Materials and methods}

\subsection{Bacterial strains}

Sampling was performed from seven highly oil-contaminated locations. Oily-polluted soils were exposed for more than 5 years to extreme weather. Locations are auto-workshops contaminated with lubricants, diesel and gasoil. Three other different oil-industrial sites in Qatar, were also used in this study (Dukhan sites).

Sampling was carried-out as previously reported. ${ }^{\mathbf{1 4}}$ The $\mathrm{pH}$ of the soil samples was ranging between 7.0 and 7.5 , and temperatures between 35 and $40{ }^{\circ} \mathrm{C}$.

Three strains were identified as $P$. aeruginosa coded QDD1, QDD8, and QDD9 (Table 1). Their identification was performed using molecular techniques by sequencing the 16S rDNA as previously reported. ${ }^{13}$ The selected strains were initially recovered from the established Qatari Hydrocarbon Degrading Strains Bank preserved in 30\% glycerol in Luria-Bertani (LB) medium at $-80{ }^{\circ} \mathrm{C}$, by streaking on solid LB medium. These strains were routinely streaked ahead for each experiment to obtain viable, fresh, and pure cells.

\subsection{Cultural media and conditions}

Maintaining of the isolates was performed in LB medium. MSM (Liquid Minimum Salt Medium) at a pH of 7.2, was composed of (per liter): a nitrogen source (Ammonium Nitrate, $\mathrm{NH}_{4} \mathrm{NO}_{3}$ ) or ammonium chloride $\left(\mathrm{NH}_{4} \mathrm{Cl}\right)$ and two phosphorus sources (mixture of $\mathrm{Na}_{2} \mathrm{HPO}_{4}$ and $\mathrm{KH}_{2} \mathrm{PO}_{4}$ ) at the concentrations specified in the experiments. Media contained $\mathrm{K}_{2} \mathrm{SO}_{4}, 0.17 \mathrm{~g}, \mathrm{MgSO}_{4}$, $7 \mathrm{H}_{2} \mathrm{O}, 0.10 \mathrm{~g}$, and $1 \mathrm{ml}$ of trace element solution composed of (in $100 \mathrm{ml}$ ): EDTA, $0.1 \mathrm{~g} ; \mathrm{ZnSO}_{4}, 0.042 ; \mathrm{MnSO}_{4}, 0.178 \mathrm{~g} ; \mathrm{H}_{3} \mathrm{BO}_{3}$, 0.05 and $\mathrm{NiCl}_{2}, 0.1 \mathrm{~g}$. All media were sterilized at $121{ }^{\circ} \mathrm{C}$ for $20 \mathrm{~min}$. Solid MSM contained Agar $15 \mathrm{~g} \mathrm{l}^{-1}$. MSM-ammonium nitrate is named MSM1 and MSM-ammonium chloride is named MSM2.

Diesel at $5 \%$ or $20 \%(\mathrm{v} / \mathrm{v})$ (as specified in the experiments) was added to the culture of a total volume of $20 \mathrm{ml}$. A stock of 
Table $1 P$. aeruginosa strains, their origin and corresponding isolation medium

\begin{tabular}{lllll}
\hline Strain & Origin & Enrichment medium for isolation & Identification & Access number \\
\hline QD11 & Polluted soil with weathered hydrocarbons (Dukhan) & MSM liquid with diesel & Pseudomonas aeruginosa & CP015377.1 \\
QDD8 & Weathered lubricants (20 years) & MSM liquid with crude oil & Pseudomonas aeruginosa & JF919950.1 \\
QDD9 & Al-Zubara site (12 years) & MSM liquid with crude oil & Pseudomonas aeruginosa & JX962695.1
\end{tabular}

diesel was furnished by a local refinery (Um-Said, Qatar, personal contact). Hydrocarbons concentration in such diesel was $750 \mathrm{~g}^{-1}$ carbon distributed between $n$-C12 and $n$-C25. C/N ratios in each culture medium were calculated considering diesel as sole carbon source, and $\mathrm{NH}_{4} \mathrm{NO}_{3}$ or $\mathrm{NH}_{4} \mathrm{Cl}$ as sole nitrogen source. Inoculation of the cultures was performed as previously reported by AlDisi et al. ${ }^{13}$ The initial biomass concentration at inoculation time was almost the same for all

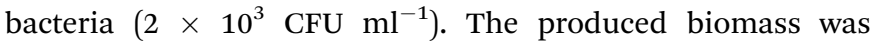
calculated as the final biomass from which the corresponding initial biomass was subtracted. Experiments were carried-out at $30{ }^{\circ} \mathrm{C}$ with incubation in a rotating shaker set at $300 \mathrm{rpm}$. Results were retrieved after one and two weeks of incubation. The produced biomass was assessed by counting the Colony Forming Units (CFU) using the serial dilution technique on LB solid medium. Experiments and the two controls were performed in triplicates. One of the two controls was the not inoculated culture and which is incubated at the same conditions. It served to evaluate the fate of diesel hydrocarbons in cultures if not degraded by bacteria. Another control was done for each isolate, but without diesel, to evidence that EDTA cannot be used as substrate.

\subsection{Factorial experimental plan}

Emerging from the original MSM components, a $2^{3}$ factorial experimental design was applied to study the influence of the main constituents of the medium on growth of the three bacterial strains and their biological activities in terms of hydrocarbons degradation. Three main parameters were chosen for the study in MSM1 medium: nitrogen source $\left[\mathrm{NH}_{4} \mathrm{NO}_{3}\right](\mathrm{X} 1)$, phosphorous source (X2) and diesel as carbon source (X3). Each factor was investigated at two levels; low and high, which were fixed following a preliminary investigation (not shown and AlDisi et $a l .{ }^{13}$ ). The two limits for the nitrogen source were $2 \mathrm{gl}^{-1}$ and $8 \mathrm{gl}^{-1}$. The concentrations of the two phosphorous sources as $\left[\mathrm{Na}_{2} \mathrm{HPO}_{4}, \mathrm{KH}_{2} \mathrm{PO}_{4}\right]$ were $1 \mathrm{~g} \mathrm{l}^{-1}$ and $0.265 \mathrm{~g} \mathrm{l}^{-1}-4 \mathrm{~g} \mathrm{l}^{-1}$ and $1.06 \mathrm{~g} \mathrm{l}^{-1}$, respectively. Diesel concentrations as carbon source were $5 \%(\mathrm{v} / \mathrm{v})$ and $20 \%(\mathrm{v} / \mathrm{v})$. Building on that, eight $\left(2^{3}\right)$ different growth conditions resulted. The other components of MSM medium were maintained in all the eight experiments. The chosen model was Linear additive model for a Completely Randomized Design (CRD).

\subsection{Analysis of diesel degradation by gas chromatography} (GC)

The capability of each strain to degrade diesel hydrocarbons was examined through Gas Chromatography Analysis (GC-FID) as previously reported in our laboratory. ${ }^{13,14}$ Removal efficiency of diesel components RE (\%) was calculated as percentage of decrease of the area corresponding to each hydrocarbon peak in the chromatograms in comparison to the abiotic control. RE $(\%)=100-\left(A_{\mathrm{s}} \times 100 / A_{\mathrm{c}}\right)$, with $A_{\mathrm{s}}$ is area of the peak, and $A_{\mathrm{c}}$ the area of the peak as obtained in the culture serving as control. ${ }^{13,15}$

Based on the technique described by Mnif et al. ${ }^{16}$ the concentrations of solubilized hydrocarbons in all the cultures including the controls were ranging from $2 \pm 2$ to $8 \pm 3 \mu \mathrm{g} \mathrm{ml} l^{-1}$ hydrocarbons. Consequently, it was concluded that removal of hydrocarbons was not due to their solubilisation in the medium considering that cultures with diesel at $10 \%$ contained $75 \mathrm{mg}$ $\mathrm{ml}^{-1}$ at the beginning of the incubation.

Since the liquid cultures were incubated at $30{ }^{\circ} \mathrm{C}$ during one and two weeks, evaporation of added diesel was minimized by performing the cultures in $50 \mathrm{ml}$ glass tubes containing $20 \mathrm{ml}$ media and tightly sealed with rubber caps. To check for the evaporation importance, the analysis of diesel fraction in the negative control culture (not inoculated) showed that the slight differences of composition compared to that of the raw diesel added to the culture media were not statistically significant at the GC-analysis conditions. Similar chromatograms were obtained.

Three replicates were performed for each experiment and the mean values with standard deviations were calculated using Microsoft Excel 2016. Significance levels of the results were analysed by using ANOVA at 95\% confidence level.

\section{5. $2^{n}$ full factorial design and statistical analysis}

Each experiment was performed in the same incubator and at the same conditions. Cultures were arranged in a completely randomized design (CRD) in factorial experiment. Each treatment was replicated three times. Analysis of variance of bacterial growth was performed, the additive model for analysis of variance was: $Y_{i j}=\mu+\mathrm{C}+\mathrm{N}+\mathrm{P}+\mathrm{C}^{*} \mathrm{~N}+\mathrm{C}^{*} \mathrm{P}+\mathrm{N} * \mathrm{P}+\mathrm{C}^{*} \mathrm{~N} * \mathrm{P}+\varepsilon_{i j}$, where $Y_{i j}$ is any growth observation reported in terms of the Colony Forming Units (CFU) in cells per ml. $\mu$ is the grand mean of all recorded observations. $\mathrm{C}, \mathrm{N}$ and $\mathrm{P}$ were the single factor effects of the concentration of carbon, nitrogen and phosphorus sources on growth, respectively. While $\left(\mathrm{C}^{*} \mathrm{~N}\right),(\mathrm{C} * \mathrm{P})$, and $\left(\mathrm{N}^{*} \mathrm{P}\right)$ are the first order interaction between two factors. The second order interaction is represented as $\left(\mathrm{C}^{*} \mathrm{~N} * \mathrm{P}\right) . \varepsilon_{i j}$ represents the experimental error. The formulated equation explains the sources of variation that can be observed in the growth results when conducting statistical analysis. A low response is coded as $(-1)$ and a high response as $(+1)$. Table 2 shows the composition of the various eight conditions in a symbolic demonstration. Multiple regression analysis was used to study the relationship between the dependent variable (biomass) $y$, and three 
Table 2 Factorial experiment model

\begin{tabular}{llll}
\hline & $\begin{array}{l}\text { Nitrogen } \\
\text { Source } \\
{\left[\mathrm{NH}_{4} \mathrm{NO}_{3}\right]\left(\mathrm{g} \mathrm{l}^{-1}\right)}\end{array}$ & $\begin{array}{l}\text { Phosphorous } \\
\text { sources } \\
{\left[\mathrm{Na}_{2} \mathrm{HPO}_{4}-\mathrm{KH}_{2} \mathrm{PO}_{4}\right]} \\
\left(\mathrm{g} \mathrm{l}^{-1}\right)\end{array}$ & $\begin{array}{l}\text { Carbon source } \\
{[\text { diesel }]} \\
(\% \mathrm{v} / \mathrm{v})\end{array}$ \\
\hline 1 & 2 & $1-0.265$ & 20 \\
2 & 2 & $4-1.06$ & 20 \\
3 & 2 & $4-1.06$ & 5 \\
4 & 2 & $1-0.265$ & 5 \\
5 & 8 & $4-1.06$ & 5 \\
6 & 8 & $1-0.265$ & 5 \\
7 & 8 & $1-0.265$ & 20 \\
8 & 8 & $4-1.06$ & 20 \\
\hline
\end{tabular}

independent variables carbon $(\mathrm{C})$, nitrogen $(\mathrm{N})$ and, phosphorus (P). The following regression equations were generated and used to estimate the theoretical yield of produced biomass:

Produced biomass of QDD9 $w_{1}=$

$$
6.28+0.450 \mathrm{C}+3.097 \mathrm{~N}-0.52 \mathrm{P}
$$

Produced biomass of QDD9 $w_{2}=$

$$
3.14+1.128 \mathrm{C}+5.04 \mathrm{~N}-3.25 \mathrm{P}
$$

Produced biomass of QDD8 $w_{1}=$

$$
10.53+0.133 \mathrm{C}+2.000 \mathrm{~N}+2.73 \mathrm{P}
$$

Produced biomass of QDD8 $w_{2}=$

$$
34.78-0.383 \mathrm{C}+1.875 \mathrm{~N}-4.51 \mathrm{P}
$$

Produced biomass of QDD1 $w_{1}=3.9+0.733 \mathrm{C}+2.67 \mathrm{~N}+6.3 \mathrm{P}$

Produced biomass of QDD1 $w_{2}=44.0-0.833 \mathrm{C}+4.47 \mathrm{~N}-8.4 \mathrm{P}$

The statistics software package Minitab (Minitab 17, 2010, Computer software, State College, PA: Minitab) was used to obtain ANOVA tables, multiple regression analysis, expected mean squares, and least square means for association analyses. Calculation of the Least Significant Difference (LSD) using the equation: $\mathrm{LSD}=t \alpha$ sqrt $(2 \mathrm{MSe} / r)$, allows examining which particular combinations of means were the source of significant variance. $t \alpha$ represents the theoretical $t$-value at significance level 0.05 and degrees of freedom of the error. MSe is the means square of the error, $r$ is the replication, which is equal to 3 in our study.

The statistics software package Minitab (Minitab 17, 2010, Computer software, State College, PA: Minitab) was used to obtain ANOVA tables, expected mean squares, and least square means for association analyses. Calculation of the Least Significant Difference (LSD) using the equation: LSD = $t \alpha$ sqrt $(2 \mathrm{MSe} / r)$, allows examining which particular combinations of means were the source of significant variance. $t \alpha$ represents the theoretical $t$-value at significance level 0.05 and degrees of freedom of the error. MSe is the means square of the error, $r$ is the replication, which is equal to 3 in our study.

\section{Results}

\subsection{Role of the medium components in growth and hydrocarbon degradation activity of $P$. aeruginosa}

To characterize the nutritional profile and the potential of diesel hydrocarbons biodegradation of three strains of $P$. aeruginosa, isolated from highly polluted soils with weathered oil in Qatar, two culture media were used. MSM1 medium contained $4 \mathrm{~g} \mathrm{l}^{-1}$ ammonium nitrate $\left(\mathrm{NH}_{4} \mathrm{NO}_{3}\right)$, providing $1.4 \mathrm{~g} \mathrm{l}^{-1} \mathrm{~N}$-ammonium nitrate. MSM2 medium contained $4 \mathrm{~g} \mathrm{l}^{-1}$ ammonium chloride $\left(\mathrm{NH}_{4} \mathrm{Cl}\right)$, providing $1.05 \mathrm{gl}^{-1} \mathrm{~N}$-ammonium chloride. In fact, this is a comparative study of two parameters; the composition of the inorganic nitrogen source added to the growth medium and the $\mathrm{C} / \mathrm{N}$ ratio. In addition, two diesel concentrations of $5 \%(\mathrm{v} / \mathrm{v})$ and $10 \%(\mathrm{v} / \mathrm{v})$ were representing the unique carbon source, which may provide information about tolerance to toxicity of each of the $P$. aeruginosa strains. Consequently, four different growth conditions resulted: MSM1 and MSM2 each with 5\% and 10\% diesel. Results of Fig. 1 show the produced biomass following growth of the 3 strains of $P$. aeruginos $a$ at the different conditions over one week of incubation. For instance, the growth of strain QDD8 significantly increased from $13 \times 10^{7}$ to $26 \times 10^{7} \mathrm{CFU}$ $\mathrm{ml}^{-1}$ in MSM2 medium, when diesel concentration was increased from $5 \%$ to $10 \%$. However, produced biomass by QDD 8 growth was significantly decreased from $28 \times 10^{7}$ to $10 \times 10^{7}$ $\mathrm{CFU} \mathrm{ml}{ }^{-1}$ in MSM1 with increase of diesel. Opposite phenomenon was observed with strain QDD9, yet growth was inhibited under higher diesel concentrations in MSM2 rather than MSM1. On the other hand, strain QDD1 maintained similar growth under the two examined nitrogen sources and $\mathrm{C} / \mathrm{N}$ ratios, while its growth was slightly enhanced when diesel concentration increased in both media. For strain QDD8, the optimal growth was at 5\% diesel and ammonium nitrate (MSM1 medium). Whilst, for strain QDD9, the optimal growth was observed with $5 \%$ diesel and ammonium chloride (MSM2 medium).

However, the evaluation of tolerance of the strains in high diesel concentrations is to be correlated to their capabilities of degrading diesel hydrocarbons at various nitrogen sources and $\mathrm{C} / \mathrm{N}$ ratios. The removal of Low Molecular Weight (LMW), Medium Molecular Weight (MMW) and High Molecular Weight (HMW) hydrocarbons was assessed by GC-FID analysis. Solubilized hydrocarbons within the aqueous phase of the culture broths (aqueous phases) were at negligible concentrations for the three strains, ranging from $2 \pm 2$ to $8 \pm 3 \mu \mathrm{g} \mathrm{ml}^{-1}$ hydrocarbons, knowing that diesel concentrations were $5 \%$ or $10 \%$ corresponding to $37.5 \mathrm{mg} \mathrm{ml}^{-1}$ or $75 \mathrm{mg} \mathrm{ml}^{-1}$ hydrocarbons, respectively at the inoculation time. A sample of the diesel layer from each culture was analysed by GC-FID, showing accurate results, compared to pre-extraction with hexane from all the culture broths (not shown). The biodegradation of diesel hydrocarbons was monitored in the cultural media (MSM) of the three $P$. aeruginosa strains. The non-inoculated medium was used as control, considered as the abiotic test and to select representative peaks, covering a wide range from the low MW hydrocarbons to high MW ones. Fig. 2 shows the chromatogram of diesel from the negative control, indicating ranges of low 


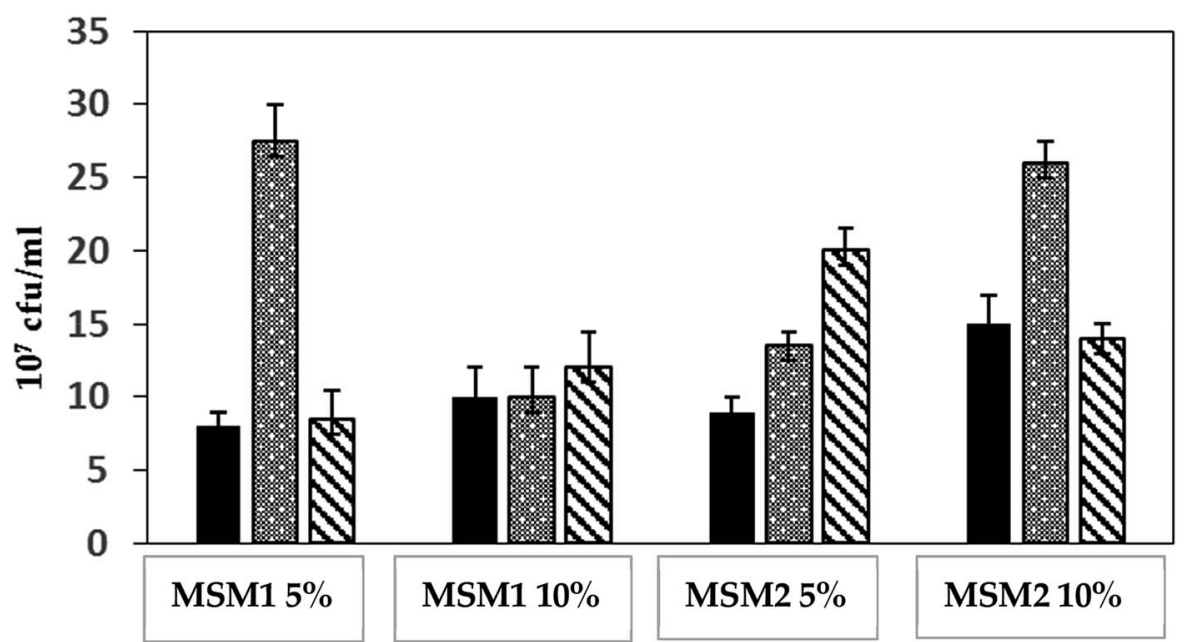

Fig. 1 Growth of $P$. aeruginosa strains on two media; MSM1 and MSM2 under 5\% and 10\% diesel over one week of incubation of $P$. aeruginosa strains: QDD1 (घ), QDD8 (涪) and QDD9 (N).

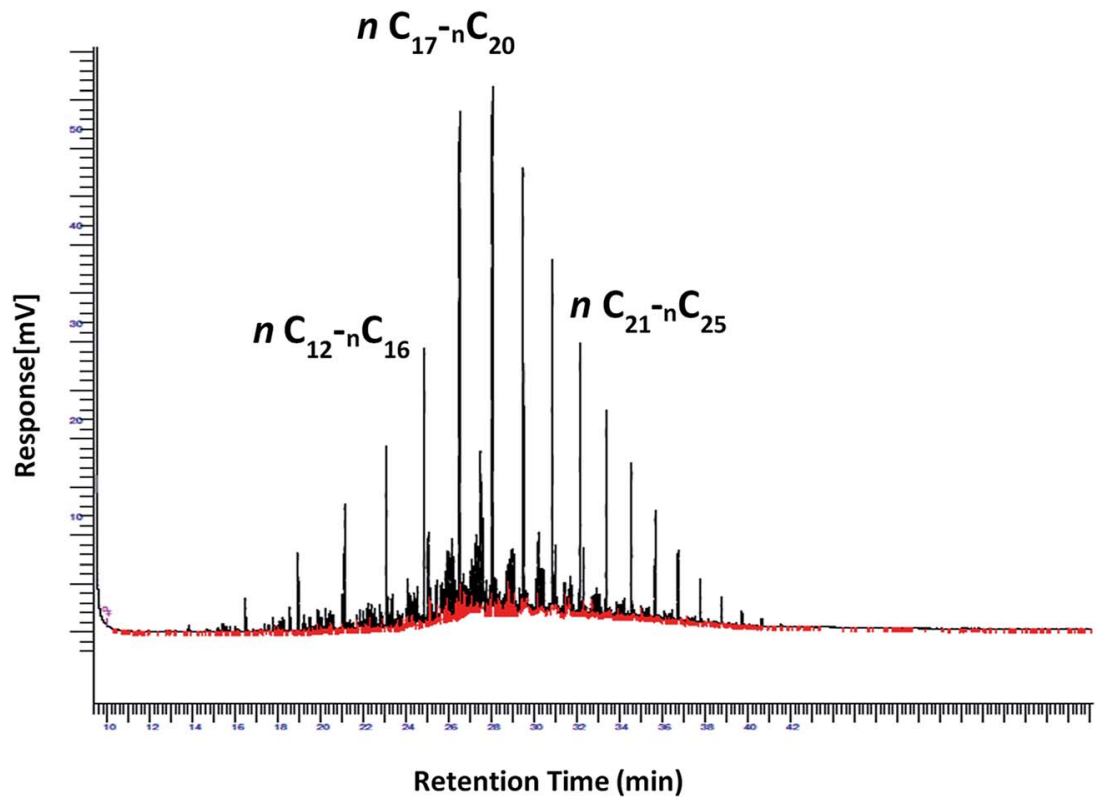

Fig. 2 Chromatogram of diesel from the negative control, indicating ranges of low ( $n$-C12- $n$-C16), medium ( $n$-C17- $n$-C20), and high ( $n$-C21- $n$ C25), molecular weight hydrocarbons corresponding to their retentions times.

(n-C12-n-C16), medium (n-C17-n-C20), and high (n-C21-n-C25), molecular weight hydrocarbons corresponding to their retention times. The hydrocarbons Removal Efficiencies (RE) of the most representative hydrocarbons grouped in the three ranges, by $P$. aeruginosa strains cultured in MSM1 and MSM2 media with $5 \%$ and $10 \%$ diesel and after one week incubation are shown in Table 3.

The GC-analysis results clearly confirm the biological capability of the studied $P$. aeruginosa strains to degrade diesel hydrocarbons under both concentrations $5 \%$ and $10 \%$. Interestingly, different removal patterns among strains could be derived from these results, showing different sensitivity of $P$. aeruginosa strains to the medium components and composition. Moreover, the three strains are able to remove high molecular weight alkanes with an efficiency of $82 \%$ to $90 \%$, in both media and at both diesel concentrations. Differences in the efficiency of the strains is more observable with removal of low and medium molecular weight hydrocarbons. By correlating growth to hydrocarbons removal, it is obviously clear that they are strongly concomitant, which is in fact expected.

\subsection{Factorial investigation of strains' potentiality to degrade diesel hydrocarbons}

Three-factors experimental strategy was based on carbon, nitrogen and phosphorous sources and two responses were monitored after one and two weeks of incubation: produced 

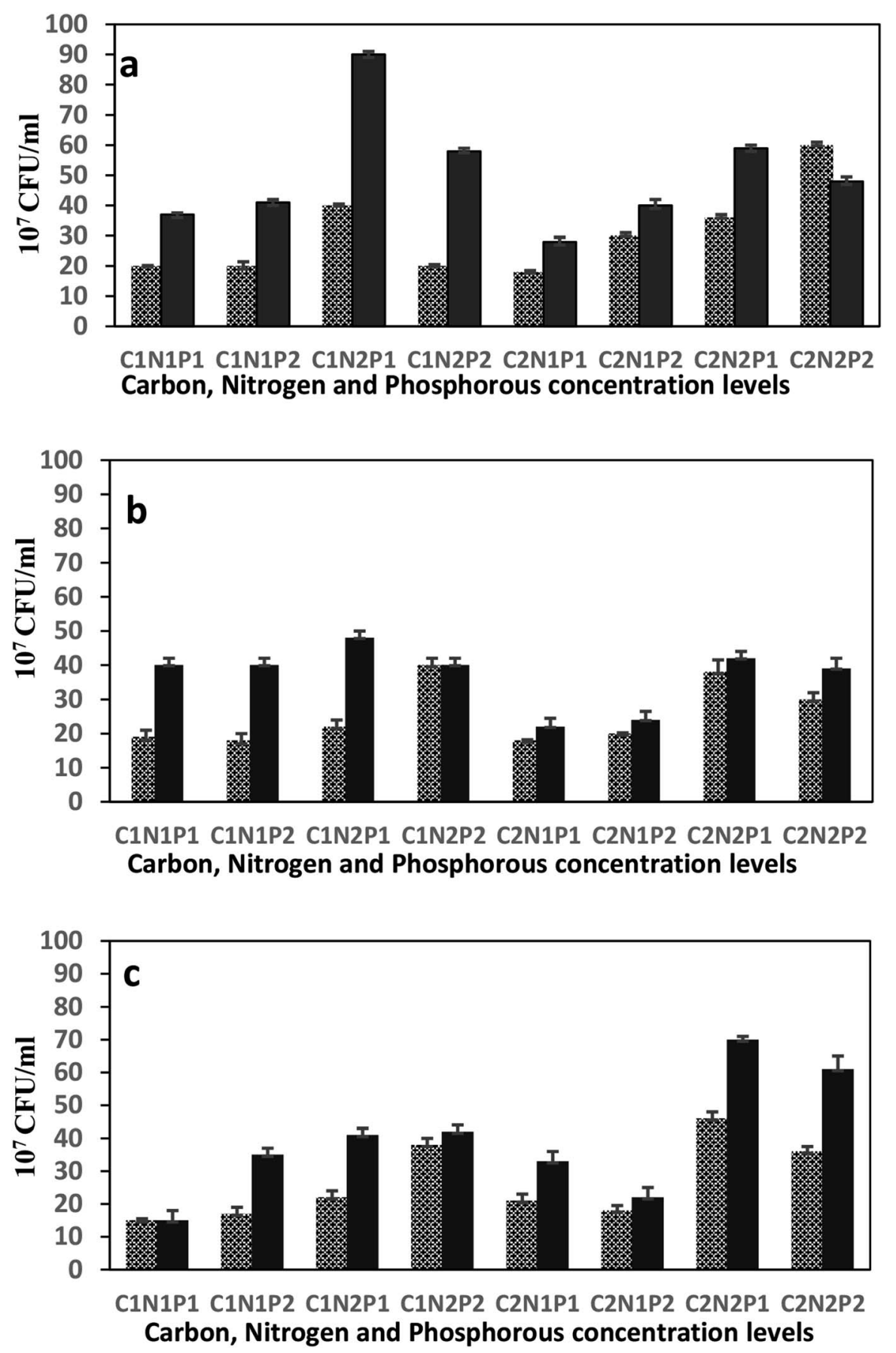

Fig. 3 Factorial investigation of the role of $C, N$ and $P$ nutritional elements in growth of $P$. aeruginosa. (a) QDD1, (b) QDD8 and (c) QDD9 over one week ( concentration of the corresponding element.

This finding confirms that an interaction of all growth parameters exists and affects the metabolism of the cells which adapts as a consequence of the evolution of the growth factors instantly available in the medium.

\subsection{Responses of $P$. aeruginosa strain QDD8}

Based on the results of the first week of incubation (Table 5), the analysis of variance of strain QDD8 growth (Table 3) showed that $\mathrm{N}$ significantly impacted the growth while $\mathrm{C}$ and $\mathrm{P}$ did not. Indeed, higher concentration of nitrogen in the medium caused significant increase of growth from $18 \times 10^{7} \mathrm{CFU} \mathrm{ml}^{-1}$ to $30 \times$ $10^{7} \mathrm{CFU} \mathrm{ml}{ }^{-1}$ (Table 4). According to ANOVA analysis, none of the first order interactions $(\mathrm{C} \times \mathrm{N}),(\mathrm{C} \times \mathrm{P})$, nor $(\mathrm{N} \times \mathrm{P})$ exhibited significant effect on cell growth. However, the second order interaction $(\mathrm{C} \times \mathrm{N} \times \mathrm{P})$ was highly significant. This means that supplying the culture medium with high 
Table 4 Overall ANOVA analysis of growth of the three P. aeruginosa strains QDD1, QDD8, and QDD9 over two-week period. Factors and their interactions are shown as $\mathrm{C}$ : carbon, $\mathrm{N}$ : nitrogen, and $\mathrm{P}$ : phosphorous ${ }^{a}$

\begin{tabular}{|c|c|c|c|c|c|c|c|}
\hline \multirow[b]{2}{*}{ Source of variation } & \multirow[b]{2}{*}{ Degree of freedom } & \multicolumn{3}{|l|}{ Week 1} & \multicolumn{3}{|l|}{ Week 2} \\
\hline & & QDD1 & QDD8 & QDD9 & QDD1 & QDD8 & QDD9 \\
\hline $\mathrm{N}$ & 1 & $1536^{* *}$ & $864^{* *}$ & $2072.04^{* *}$ & $4320.2^{* *}$ & $759.38^{* *}$ & $5490.4^{* *}$ \\
\hline $\mathrm{P}$ & 1 & $150^{* *}$ & $28.17 \mathrm{~ns}$ & $1.04 \mathrm{~ns}$ & $266.7^{* *}$ & $77.04 \mathrm{~ns}$ & $40 \mathrm{~ns}$ \\
\hline $\mathrm{C}^{*} \mathrm{~N}$ & 1 & $308.17^{* *}$ & $0.67 \mathrm{~ns}$ & $51.04 \mathrm{~ns}$ & $400.2^{* *}$ & $176.04^{*}$ & $376^{*}$ \\
\hline $\mathrm{C}^{*} \mathrm{~N} * \mathrm{P}$ & 1 & $384^{* *}$ & $308.17^{* *}$ & $145.04^{*}$ & $192.7^{* *}$ & $45.38 \mathrm{~ns}$ & $26 \mathrm{~ns}$ \\
\hline Error & 16 & 11.46 & 36.46 & 24.04 & 17.7 & 32.83 & 72.9 \\
\hline
\end{tabular}

$a *$ indicates that the difference between means is significant, ** indicates that the difference between means is highly significant, and (ns) indicates that the difference between means is not significant.

concentrations of carbon, nitrogen, and phosphorous had significant impact on the growth of strain QDD8. The combination that showed the highest significant difference was $(\mathrm{C} 1 \mathrm{~N} 1 \mathrm{P} 2 * \mathrm{C} 1 \mathrm{~N} 2 \mathrm{P} 2)$. Under this cultural condition, growth increased significantly from $16.3 \times 10^{7} \mathrm{CFU} \mathrm{ml}^{-1}$ to $36.7 \times 10^{7}$ $\mathrm{CFU} \mathrm{ml}^{-1}$ (Table 5). The highest cell growth of $36.7 \times 10^{7} \mathrm{CFU}$ $\mathrm{ml}^{-1}$ was noticed under the condition C1N2P2. Strain QDD8 demonstrated different behaviour in the second week of growth. The analysis of variance showed that the $\mathrm{C}$ effect became significant as well as the $\mathrm{N}$ effect. Although, phosphorous effect remained insignificant. Noticeably, growth exhibited a decrease from $39.25 \times 10^{7} \mathrm{CFU} \mathrm{ml}^{-1}$ to $33.5 \times 10^{7}$ $\mathrm{CFU} \mathrm{ml} \mathrm{m}^{-1}$ when carbon concentration was increased in the medium from $5 \%$ to $20 \%$. However, when nitrogen was increased in the medium from $2 \mathrm{~g} \mathrm{l}^{-1}$ to $8 \mathrm{~g} \mathrm{l}^{-1}$, growth increased from 30.75 to $42 \times 10^{7} \mathrm{CFU} \mathrm{ml}^{-1}$ (Table 5).

The CFUs obtained experimentally after one week of growth were in general slightly higher if not similar by comparing to the theoretical values. This is not statistically significant in all cultural conditions after two weeks of growth, as shown by

Table 5 Triplicate average growth of $P$. aeruginosa strains QDD1, QDD8 and QDD9 over week 1 and week 2 incubations, as determined experimentally (Exp.). Multiple regression analysis was used to calculate the theoretical values (Theo.). (I) First order interactions (C*N), (II) first order interactions $(C * P)$, (III) first order interaction $(N * P)$, (IV) second order interactions $(C * N * P)$. The values indicated with one level of one parameter and the other parameter without level means the average growth at the low levels of the second

\begin{tabular}{|c|c|c|c|c|c|c|c|c|c|c|c|c|c|}
\hline \multirow{2}{*}{$\begin{array}{l}\text { Cultural } \\
\text { conditions }\end{array}$} & \multirow{2}{*}{$\begin{array}{l}\text { Order of } \\
\text { interactions }\end{array}$} & \multicolumn{12}{|c|}{ Mean produced biomass $\left(10^{7} \mathrm{CFU} \mathrm{ml}^{-1}\right)$} \\
\hline & & Exp. & Theo. & Exp. & Theo. & Exp. & Theo. & Exp. & Theo. & Exp. & Theo. & Exp. & Theo. \\
\hline $\mathrm{C} 1 \mathrm{~N} 1$ & I & 20.7 & 12.9 & 17.2 & 15.2 & 15.8 & 14.7 & 39.2 & 48.8 & 20.7 & 36.6 & 20.7 & 18.9 \\
\hline $\mathrm{C} 2 \mathrm{~N} 1$ & & 24.5 & 23.9 & 18.8 & 17.2 & 19.7 & 21.5 & 34.8 & 36.3 & 43.0 & 30.9 & 29.7 & 35.8 \\
\hline $\mathrm{C} 2 \mathrm{~N} 2$ & & 47.7 & 39.9 & 31.2 & 29.2 & 41.2 & 40.1 & 53.5 & 63.1 & 67.8 & 42.1 & 65.9 & 66.0 \\
\hline C1P1 & II & 29.5 & 9.2 & 19.5 & 11.9 & 20.0 & 8.4 & 63.8 & 37.6 & 29.0 & 31.7 & 29.0 & 7.9 \\
\hline $\mathrm{C} 1 \mathrm{P} 2$ & & 20.7 & 14.2 & 26.5 & 14.1 & 27.4 & 8.0 & 49.5 & 30.9 & 54.2 & 28.1 & 34.7 & 5.3 \\
\hline $\mathrm{C} 2 \mathrm{P} 1$ & & 26.7 & 20.2 & 26.3 & 13.9 & 34.5 & 15.1 & 43.7 & 25.1 & 34.7 & 25.9 & 54.2 & 24.8 \\
\hline $\mathrm{C} 2 \mathrm{P} 2$ & & 45.5 & 25.2 & 23.7 & 16.1 & 26.4 & 14.7 & 44.7 & 18.4 & 43.3 & 22.3 & 43.3 & 22.3 \\
\hline C1N1P2 & & 21.3 & 19.6 & 16.3 & 18.1 & 16.7 & 14.2 & 43.0 & 39.9 & 37.0 & 31.8 & 26.3 & 15.4 \\
\hline C1N2P1 & & 39.0 & 30.6 & 21.0 & 27.9 & 25.0 & 33.2 & 92.3 & 73.4 & 47.3 & 46.7 & 43.0 & 48.2 \\
\hline $\mathrm{C} 1 \mathrm{~N} 2 \mathrm{P} 2$ & & 20.0 & 35.6 & 36.7 & 30.1 & 38.0 & 32.8 & 56.0 & 66.7 & 37.0 & 43.1 & 43.0 & 45.7 \\
\hline C2N1P1 & & 18.0 & 25.6 & 17.3 & 17.9 & 21.7 & 21.3 & 29.0 & 34.1 & 26.3 & 29.7 & 34.3 & 34.9 \\
\hline $\mathrm{C} 2 \mathrm{~N} 1 \mathrm{P} 2$ & & 31.0 & 30.6 & 20.3 & 20.1 & 17.7 & 20.9 & 40.7 & 27.4 & 24.0 & 26.1 & 25.0 & 32.3 \\
\hline $\mathrm{C} 2 \mathrm{~N} 2 \mathrm{P} 1$ & & 35.3 & 41.6 & 35.3 & 29.9 & 47.3 & 39.9 & 58.3 & 60.9 & 43.3 & 40.9 & 74.0 & 65.2 \\
\hline $\mathrm{C} 2 \mathrm{~N} 2 \mathrm{P} 2$ & & 60.0 & 46.6 & 27.0 & 32.1 & 35.0 & 39.5 & 48.7 & 54.2 & 40.3 & 37.3 & 61.7 & 62.6 \\
\hline Mean & & 30.6 & 25.2 & 24.0 & 21.3 & 27.0 & 22.9 & 50.4 & 49.1 & 38.7 & 36.1 & 40.2 & 32.9 \\
\hline
\end{tabular}


comparisons between the theoretical $v s$. experimental biomass, conducted using paired $t$-test (data are not shown). Here, adaptation of the metabolism of the cells is clear depending on the interaction between the studied growth parameters.

\subsection{Responses of $P$. aeruginosa strain QDD1}

Strain QDD1 demonstrated quite interesting results upon the analysis of variance (ANOVA). Most of its growth showed highly significant differences. The main effects of the three factors indicated that all $\mathrm{C}, \mathrm{N}$, and $\mathrm{P}$ have highly significant impact on cell growth (Table 4). As shown in Table 5, in the first week of incubation, growth had increased from $25.1 \times 10^{7} \mathrm{CFU} \mathrm{ml}^{-1}$ to $36.1 \times 10^{7} \mathrm{CFU} \mathrm{ml}^{-1}$ when carbon was increased in the medium from $5 \%$ to $20 \%$ diesel. In addition, high nitrogen concentration caused the cells to grow from $22.6 \times 10^{7} \mathrm{CFU} \mathrm{ml}^{-1}$ to 38.6 $\times 10^{7} \mathrm{CFU} \mathrm{ml}{ }^{-1}$. Further, when phosphorous represented as $\left[\mathrm{Na}_{2} \mathrm{HPO}_{4}, \mathrm{KH}_{2} \mathrm{PO}_{4}\right]$ was increased in the medium from $1 \mathrm{~g} \mathrm{l}^{-1}$ and $0.265 \mathrm{~g} \mathrm{l}^{-1}$ to $4 \mathrm{~g} \mathrm{l}^{-1}$ and $1.06 \mathrm{~g} \mathrm{l}^{-1}$ respectively, produced biomass increased significantly from $28.1 \times 10^{7} \mathrm{CFU} \mathrm{ml}^{-1}$ to $33.1 \times 10^{7} \mathrm{CFU} \mathrm{ml}^{-1}$ (Table 5). First order interaction of both $(\mathrm{C}$ $\times \mathrm{P})$ and $(\mathrm{C} \times \mathrm{N})$ were highly significant, unlike the $(\mathrm{N} \times \mathrm{P})$ which was not. In both significant interactions, the only insignificant combinations were $\left(\mathrm{C} 1 \mathrm{~N} 1{ }^{*} \mathrm{C} 2 \mathrm{~N} 1\right)$ and $\left(\mathrm{C} 1 \mathrm{P} 1{ }^{*} \mathrm{C} 2 \mathrm{P} 1\right)$ according to the LSD calculations. In other words, maintaining $\mathrm{N}$ and $\mathrm{P}$ low makes the increase in carbon concentration ineffective in raising the growth significantly. Examining the second order interaction $(\mathrm{C} \times \mathrm{N} \times \mathrm{P})$, ANOVA results showed that it had significant effect on growth. When computing LSD between the means, the largest significant difference was detected in $(\mathrm{C} 2 \mathrm{~N} 1 \mathrm{P} 1 * \mathrm{C} 2 \mathrm{~N} 2 \mathrm{P} 2)$. Shifting the growth medium conditions from low $\mathrm{N}$ and $\mathrm{P}$ to high $\mathrm{N}$ and $\mathrm{P}$ while keeping $\mathrm{C}$ in high concentration (20\% diesel) increased the biomass production from $18 \times 10^{7} \mathrm{CFU} \mathrm{ml}^{-1}$ to $60 \times 10^{7}$ CFU ml ${ }^{-1}$ (Table 5). In fact, the cultural condition that showed the highest growth of strain QDD1 in week 1 was C2N2P2. By the second week, all the analysed factors seemed to have high significant effect on cell growth. This means that single factor effect of $\mathrm{C}, \mathrm{N}$, and $\mathrm{P}$, besides the first and the second order interactions were all significant. However, growth decreased significantly from $56.7 \times 10^{7} \mathrm{CFU} \mathrm{ml}^{-1}$ to $44.15 \times 10^{7} \mathrm{CFU} \mathrm{ml}^{-1}$ when carbon was added to the medium in high concentration. Growth also witnessed a decrease from $53.75 \times 10^{7} \mathrm{CFU} \mathrm{ml}^{-1}$ to $47.1 \times 10^{7} \mathrm{CFU} \mathrm{ml}^{-1}$ when phosphorous was raised. Dissimilarly, when nitrogen concentration was increased up to $8 \mathrm{~g} \mathrm{l}^{-1}$, cell growth increased significantly from $37 \times 10^{7} \mathrm{CFU} \mathrm{ml}^{-1}$ to $63.85 \times 10^{7} \mathrm{CFU} \mathrm{ml}^{-1}$ (Table 5). In the first order interactions, the source of significance was not from the following combinations $\left(\mathrm{C} 1 \mathrm{~N} 1{ }^{*} \mathrm{C} 2 \mathrm{~N} 1\right),\left(\mathrm{C} 2 \mathrm{P} 1{ }^{*} \mathrm{C} 2 \mathrm{P} 2\right)$, or $\left(\mathrm{C} 1 \mathrm{P} 2{ }^{*} \mathrm{C} 2 \mathrm{P} 2\right)$. Unlike all other strains, the interaction $\left(\mathrm{N}^{*} \mathrm{P}\right)$ is significant with all its combinations in week 2 for strain QDD1. As carbon concentration is kept constant in the medium, $(\mathrm{N} 2 \times \mathrm{P} 1)$ allowed cells to grow up to $75.3 \times 10^{7} \mathrm{CFU} \mathrm{ml}^{-1}$. LSD results from the second order interaction $(\mathrm{C} \times \mathrm{N} \times \mathrm{P})$ brought out that moving cells from the medium containing low $\mathrm{C}$, high $\mathrm{N}$, low $\mathrm{P}$ to the medium containing high $\mathrm{C}$ and low $\mathrm{N}$ and $\mathrm{P}$ had the highest significant difference. However, the highest biomass production was obtained under the interaction $(\mathrm{C} 1 \times \mathrm{N} 2 \times \mathrm{P} 1)$ (Table 5).

By comparing to the theoretical values, the CFUs obtained experimentally after one week of growth were much higher, reminding the results obtained with QDD9. After two weeks of growth, this is still applicable for most of the conditions. The interactions among the three factors are then highly observed at the cultural conditions in which the metabolism of the cells shall adapt as a consequence of the available nutrients to use hydrocarbons for growth.

\subsection{Impact of growth requirements on $P$. aeruginosa activity profiles for diesel hydrocarbons degradation}

In correlation with the growth analysis, hydrocarbons removal was assessed using GC-analysis in the diesel layer from each growth condition. Table 6 shows the RE of each strain under four selected representative growth conditions. As the coding implies, condition C1N2P1 contains low carbon (diesel) concentration $5 \%(\mathrm{v} / \mathrm{v})$, low nitrogen concentration $\left(2 \mathrm{~g} \mathrm{l}^{-1}\right.$ $\left.\mathrm{NH}_{4} \mathrm{NO}_{3}\right)$, and high phosphorous concentration $\left(4 \mathrm{~g} \mathrm{l}^{-1}\right.$ and $1.06 \mathrm{~g} \mathrm{l}^{-1}$ of $\mathrm{Na}_{2} \mathrm{HPO}_{4}$ and $\mathrm{KH}_{2} \mathrm{PO}_{4}$ respectively). While condition $\mathrm{C} 2 \mathrm{~N} 2 \mathrm{P} 2$ consisted of high carbon concentration $(20 \%(\mathrm{v} / \mathrm{v})$ diesel), high nitrogen concentration $\left(8 \mathrm{~g} \mathrm{l}^{-1} \mathrm{NH}_{4} \mathrm{NO}_{3}\right)$, and high phosphorous concentration $\left(4 \mathrm{~g} \mathrm{l}^{-1}\right.$ and $1.06 \mathrm{~g} \mathrm{l}^{-1}$ of $\mathrm{Na}_{2} \mathrm{HPO}_{4}$ and $\mathrm{KH}_{2} \mathrm{PO}_{4}$ respectively).

Removal efficiencies of each strain under representative growth conditions for the three strains, further support the diversity of biological activity among the three $P$. aeruginosa strains. Biodegradation of diesel hydrocarbons varied considerably under different growth conditions. For instance, under growth condition C1N1P2, hydrocarbon removal was much higher for strains QDD8 and QDD9 compared to QDD1. On the other hand, when nutrients were at maximum concentrations, strains QDD1 and QDD8 exhibited lower hydrocarbons RE than

Table 6 Removal Efficiencies (RE) of hydrocarbons grouped in the three ranges, by the isolated strains cultured at four representative growth conditions coded C1N1P2, C2N2P2, C1N1P1 and C1N2P1 and after two weeks incubation. Carbon source was $5 \%(\mathrm{v} / \mathrm{v})$ as $\mathrm{C} 1$ and $20 \%$ $(\mathrm{v} / \mathrm{v})$ as $\mathrm{C} 2, \mathrm{~N}$ : nitrogen source $\left[\mathrm{NH}_{4} \mathrm{NO}_{3}\right]$ was $2 \mathrm{~g} \mathrm{l}^{-1}$ as $\mathrm{N} 1$ and $8 \mathrm{~g} \mathrm{l}^{-1}$ as $\mathrm{N} 2$, and P: phosphorous sources as $\left[\mathrm{Na}_{2} \mathrm{HPO}_{4}, \mathrm{KH}_{2} \mathrm{PO}_{4}\right]$ were $1 \mathrm{gl}^{-1}$, $0.265 \mathrm{~g} \mathrm{l}^{-1}$ as P1 and $4 \mathrm{~g} \mathrm{l}^{-1}, 1.06 \mathrm{~g} \mathrm{l}^{-1}$ as P2

\begin{tabular}{lllll}
\hline Removal efficiency (\%) & C1N1P2 & C2N2P2 & C1N1P1 & C1N2P1 \\
\hline QDD1 & & & & \\
LMW hydrocarbons & $47 \pm 3$ & $43 \pm 3$ & $38 \pm 2$ & $58 \pm 2$ \\
MMW hydrocarbons & $53 \pm 2$ & $56 \pm 3$ & $46 \pm 2$ & $66 \pm 2$ \\
HMW hydrocarbons & $74 \pm 3$ & $70 \pm 3$ & $50 \pm 3$ & $67 \pm 3$
\end{tabular}

QDD8

LMW hydrocarbons

MMW hydrocarbons

HMW hydrocarbons

$\begin{array}{llll}79 \pm 2 & 54 \pm 3 & 33 \pm 2 & 62 \pm 2 \\ 75 \pm 3 & 53 \pm 2 & 41 \pm 2 & 61 \pm 2 \\ 88 \pm 3 & 71 \pm 3 & 54 \pm 3 & 63 \pm 3\end{array}$

QDD9

$\begin{array}{lllll}\text { LMW hydrocarbons } & 69 \pm 3 & 78 \pm 3 & 48 \pm 2 & 64 \pm 2\end{array}$ $\begin{array}{lllll}\text { MMW hydrocarbons } & 68 \pm 2 & 72 \pm 3 & 49 \pm 2 & 62 \pm 2\end{array}$ HMW hydrocarbons $\quad 82 \pm 3 \quad 87 \pm 3 \quad 59 \pm 3 \quad 71 \pm 3$ 
QDD9. Under minimal nutrients concentrations (C1N1P1) strains exhibited low removal activity. However, when nitrogen was supplied at maximal concentration while $\mathrm{C}$ and $\mathrm{P}$ were minimal as in condition (C1N2P1), removal was improved.

\section{Discussion}

In order to demonstrate the sensitivity of hydrocarbondegrading bacterial growth and biological activity to $\mathrm{C}, \mathrm{N}$ and $P$ balance, three strains of $P$. aeruginosa isolated after long adaptation at harsh conditions with weathered hydrocarbons were cultured at a set of media composition. Statistical analysis demonstrated variability of the final biomass produced by the three strains of $P$. aeruginosa, in media with different combinations of $\mathrm{C}, \mathrm{N}$ and $\mathrm{P}$ concentrations and ratios, indicating that growth and tolerance to toxicity are highly dependent on the components of the culturing medium. Some strains may be tolerant to higher diesel concentrations in a medium, but not in another. Even that all the strains belong to $P$. aeruginosa species, they exhibited different activities at various growth conditions, showing high variability of potency within the same group of $P$. aeruginosa isolates. Knowing that degradation of hydrocarbons by bacteria is a complex process, these findings showed that the nutritional requirements and nutrients availability as well as the concentration of hydrocarbons present may play the key role in the hydrocarbons degradation activity among hydrocarbondegrading bacteria. Our findings confirm the previous speculations of Jasmine and Mukherji, ${ }^{17}$ who showed that the nutrients availability as well as their concentrations present in the microenvironment of the microbial cells would affect hydrocarbon degradation. Inhibition of microbial growth under high diesel concentrations has been reported in several bioremediation studies. ${ }^{17}$ In fact, diesel at certain concentrations could be toxic to microorganisms via the solvent impacts that can alter the plasma membrane. ${ }^{18,19}$

Interestingly, the three studied $P$. aeruginosa strains have tolerated a high diesel concentration of $10 \%(\mathrm{v} / \mathrm{v})$ in same media and cultural conditions. The components of the medium seemed to contribute in the change of the membrane properties, from which results a different sensitivity to the solvent effect. This may be considered in selecting candidates and fixing the nutritional requirements of $P$. aeruginosa in bioremediation applications in oily-polluted soils. The spectrum of hydrocarbons removal is indicative, but cannot be the only information source of the ability of each strain to degrade hydrocarbons. Some hydrocarbons may be converted or partially degraded while others are removed. The pattern of activity of each hydrocarbon-degrading $P$. aeruginosa strain is then interestingly studied in the complex mixture of hydrocarbons in diesel. The study of the role of two nitrogen sources and two diesel concentrations providing different $\mathrm{C} / \mathrm{N}$ ratios using three strains of $P$. aeruginosa spotted the light on how crucial is the nutritional microenvironment in influencing growth as well as the biological activities of bacterial strains. However, there is a gap in understanding the role of nutritional elements such as carbon, nitrogen, and phosphorous in growth of $P$. aeruginosa for hydrocarbon-biodegradation in complex hydrocarbon mixtures, knowing the complexity of the biodegradative pathways which are highly dependent on the metabolic pathways. In literature, estimation of $\mathrm{C} / \mathrm{N} / \mathrm{P}$ ratios was always based on removal of categories of hydrocarbons or for the complete mineralization in absence of weathering processes. In addition, the originality of this work is the attempt to integrate the study of the most essential nutritional elements as well as their interactions. Results emphasized the role of nitrogen in enhancing both growth and biological activity of hydrocarbon degrading strains as previously speculated by Braddock et al. ${ }^{20}$ Furthermore, strains were generally able to attack high MW hydrocarbons only by the second week. As time passes, cells are able to produce larger quantities of bio-surfactants that facilitate the cell/diesel interaction and thus biodegradation. ${ }^{21}$ Here, it is clearly shown, that this differs from one $P$. aeruginos $a$ strain to another depending on the medium components. Obviously, nutrients concentration plays a critical role in hydrocarbons biodegradation activity of bacterial strains. Nevertheless, neither excess nor minimal concentrations are favourable for strains to express good biological removal of categories of hydrocarbons, which evidences the previous observations of Braddock et al. ${ }^{20}$ Hence, the highest growth of a strain is not always translated into the highest RE of hydrocarbons. In fact, the biological activity involved in degradation of diesel hydrocarbons is complex, many bioconversion reactions may occur. Further, the cultural media may lead to production of different molecules and different concentrations of surfactants, which are key tools involved in hydrocarbons biodegradation. This may explain the fluctuations observed at different compositions (especially nitrogen) and among strains. Moreover, GC-analysis, as RE, showed fluctuations from one week to another, one condition to another, and one strain to another. This might lead to a clearer view of the optimal growth condition under which each strain produces considerable biomass and favour hydrocarbon removal. Nevertheless, the statistical investigation carried-out using Analysis of Variance (ANOVA) allowed to test the significance of differences among two or more means (populations) which in turn allowed to show the high variability in the impact of the growth parameters on the biological activity among the three strains of $P$. aeruginosa. It was clearly observed that higher nitrogen concentration increased cells growth significantly of all strains both in the first and second week of incubation. All strains were positively sensitive to nitrogen concentration in the medium. However, growth of strains generally seemed to be less affected by phosphorous concentration variation as was similarly observed by Coulon et al. ${ }^{22}$ In fact, it is known that attempts to enhance hydrocarbon degradation were usually reported by the addition of supplemental nitrogen and to a lesser degree phosphorous..$^{21,23}$ Some strains were found to be more sensitive (e.g., QDD1) to $\mathrm{C} / \mathrm{N} / \mathrm{P}$ ratio than others (e.g., QDD8). Yet, C/N/P ratios were generally more limiting factors in the first week of the growth. However, the growth might turn into saturation and the three-factor interactions are no longer significant by the second week of growth. High behavioural variability exists within the group of three $P$. aeruginosa strains, isolated from harsh conditions, more demonstrating variability in nutritional requirements for 
hydrocarbons degradation by each isolate. A specific adaptation event to specific environmental conditions occurs with each bacterial strain. This conclusion is confirmed by calculation of the theoretical yield of produced biomass for the different bacterial strains, by multiple regression analysis, based on the relationship between the dependent variable (biomass) $\mathrm{y}$, and three independent variables carbon (C), nitrogen (N) and, phosphorus (P). Comparisons between the theoretical $v s$. experimental biomass was conducted using paired $t$-test (data are not shown). In general, all bacterial strains showed significant higher experimental yield of produced biomass compared to the theoretical except some interactions at week 2 . These results indicate that the effect of the growth parameters continuously affect the metabolism of the cells in media containing hydrocarbons as sole carbon sources. The metabolism of degradation of hydrocarbons is then highly sensitive to $\mathrm{C}, \mathrm{N}$ and $\mathrm{P}$ ratios. This is quantitatively and statistically demonstrated for the first time. This is to be considered in selecting appropriate $P$. aeruginosa isolates for bioaugmentation/ biostimulation approaches in remediating each oily-polluted soil.

\section{Conclusions}

Three strains of $P$. aeruginosa isolated from soils, highly polluted with weathered oil at harsh weather and soils exhibited different growth and hydrocarbon-degrading capabilities as shown using a $2^{3}$ full factorial design. This diversity was related to the three major nutritional parameters in the MSM medium which are carbon, nitrogen and phosphorous sources. Growth and tolerance to toxicity were shown to be highly dependent on the components of the culturing medium. First order and second order interactions showed high variability in the impact of nutrients on the biological activity among the three strains of $P$. aeruginosa. Moreover, some strains were shown to be more sensitive to $\mathrm{C} / \mathrm{N} / \mathrm{P}$ ratio than others, but each with different behaviour. Removal and/ or conversion of diesel hydrocarbons were shown highly sensitive to the balance of the nutrients and vary from one $P$. aeruginosa strain to another. These findings clearly show high diversity of $P$. aeruginosa metabolism involved in hydrocarbon degradation. Using raw diesel as source of mixed hydrocarbons was one of the factors allowing detection of such diversity rather than using pure hydrocarbon-based media. This is important from the practical point of view in selecting and implementing appropriate $P$. aeruginosa isolates in bioremediation approaches.

\section{Conflicts of interest}

The authors declare no conflict of interest. All Authors decided to publish this work. The founding sponsors had no role in the design of the study; in the collection, analyses, or interpretation of data; in the writing of the manuscript, and in the decision to publish the results.

\section{Acknowledgements}

This work was supported by the College of Arts and Sciences and Department of biological and Environmental Sciences of Qatar University [QUUG-CAS-DEM-12/13-6; QUST-CAS-FALL-12/ 13-23; QUST-CAS-FALL-12/13-22].

\section{References}

1 N. Das and P. Chandran, Microbial Degradation of Petroleum Hydrocarbon Contaminants: An Overview, Biotechnol. Res. Int., 2011, 1-13.

2 A. K. Karamalidis, A. C. Evangelou, E. Karabika, A. I. Koukkou, C. Drainas and E. A. Voudrias, Laboratory scale bioremediation of petroleum-contaminated soil by indigenous microorganisms and added Pseudomonas aeruginosa strain Spet, Bioresour. Technol., 2010, 101, 6545.

3 R. Atlas and T. Hazen, Oil biodegradation and bioremediation: a tale of the two worst spills in U.S. history, Environ. Sci. Technol., 2009, 45, 6709-6715.

4 B. Gargouri, F. Karray, N. Mhiri, F. Aloui and S. Sayadi, Bioremediation of petroleum hydrocarbons contaminated soil by bacterial consortium isolated from an industrial wastewater treatment plan, J. Chem. Technol. Biotechnol., 2014, 39, 978-987.

5 K. Ziervogel, L. McKay, B. Rhodes, C. Osburn, J. DicksonBrown, C. Arnosti and A. Teske, Microbial Activities and Dissolved Organic Matter Dynamics in Oil-Contaminated Surface Seawater from the Deepwater Horizon Oil Spill Site, PLoS One, 2010, 7, 34816.

6 S. Samanta, O. Singh and R. Jain, Polycyclic aromatic hydrocarbons: Environmental pollution and bioremediation, Trends Biotechnol., 2002, 20, 243-248.

7 M. Kastner, M. Breuer-Jammlia and B. Mahroe, Enumeration and characterization of the soil microflora from hydrocarbon contaminated soil sites able to mineralize Polycyclic Aromatic Hydrocarbon (PAH), Appl. Microbiol. Biotechnol., 1994, 41, 267-273.

8 A. R. Johnsen, S. Schmidt, K. T. Hybholt, S. Henriksen, S. C. Jacobsen and O. Anderson, Strong Impact on the Polycyclic Aromatic Hydrocarbon (PAH)-Degrading Community of a PAH-Polluted Soil but Marginal Effect on PAH Degradation when Priming with Bioremediated Soil Dominated by Mycobacteria, Appl. Environ. Microbiol., 2007, 73, 1474-1480.

9 S. K. Lotfabad and M. R. Gray, Kinetics of biodegradation of mixtures of polycyclic aromatic hydrocarbons, Appl. Microbiol. Biotechnol., 2002, 60, 361-365.

10 A. Masih and A. Taneja, Polycyclic Aromatic Hydrocarbons (PAHs) concentrations and related carcinogenic potencies in soil at a semi-arid region of India, Chemosphere, 2006, 65, 449-456.

11 E. C. Santos, J. S. R. Jacques, M. F. Bento, R. Peralba and P. A. Selbach, Anthracene biodegradation and surface activity by an iron-stimulated Pseudomonas sp, Bioresour. Technol., 2008, 99, 2644-2649. 
12 O. Nwinyi, I. Kanu, A. Tunde and K. Ajanaku, Characterization of diesel degrading bacterial species from contaminated tropical ecosystem, Braz. Arch. Biol. Technol., 2014, 57, 789-796.

13 Z. AlDisi, S. Jaoua, D. AlThani, S. Almeer and N. Zouari, Considering the specific impact of harsh conditions and oil weathering on diversity, adaptation and activity of hydrocarbon degrading bacteria in strategies of bioremediation of harsh oily-polluted soils, BioMed Res. Int., 2017, 8649350, DOI: 10.1155/2017/8649350.

14 N. S. AlKaabi, M. Kristensen, N. Zouari, T. T. Solling, S. S. Bach, M. Al-Ghouti and J. H. Christensen, Source identification of beached oil at Al Zubarah, Northwestern Qatar, J. Pet. Sci. Eng., 2017, 149, 107-113.

15 L. Michaud, A. Giudice, M. Saitta, M. Domenico and V. Bruni, The biodegradation efficiency on diesel oil by two psychrotrophic Antarctic marine bacteria during a twomonth-long experiment, Mar. Pollut. Bull., 2004, 49, 405409.

16 I. Mnif, S. Chaabouni-Ellouze and D. Ghribi, Optimization of the Nutritional Parameters for Enhanced Production of $B$. subtilis SPB1 Biosurfactant in Submerged Culture Using Response Surface Methodology, Biotechnol. Res. Int., 2012, 2012, 1-8.

17 J. Jasmine and S. Mukherji, Evaluation of bioaugmentation and biostimulation effects on the treatment of refinery oily sludge using $2^{n}$ full factorial design, Environ. Sci.: Processes Impacts, 2014, 16, 1889-1896.

18 M. Shukor, N. Hassan, A. Jusoh, N. Perumal, N. Shamaan, W. MacCormack and M. Syed, Isolation and characterization of a Pseudomonas diesel-degrading strain from Antarctica, J. Environ. Biol., 2009, 30, 1-6.

$19 \mathrm{H}$. Heipieper and P. Martínez, Toxicity of Hydrocarbons to Microorganisms, Handbook of Hydrocarbon and Lipid Microbiology, 2010, vol. 2010, pp. 1563-1573.

20 J. Braddock, M. Ruth, P. Catterall, J. Walworth and K. McCarthy, Enhancement and inhibition of microbial activity in hydrocarbon-contaminated Arctic soils: implications for nutrient-amended bioremediation, Environ. Sci. Technol., 1997, 31, 2078-2084.

21 W. Xia, Q. Cui, H. Dong, F. Wang, P. He and Y. Tang, Biosurfactant produced by novel Pseudomonas sp. WJ6 with biodegradation of $n$-alkanes and polycyclic aromatic hydrocarbons, J. Hazard. Mater., 2014, 276, 489-498.

22 F. Coulon, E. Pelletier, L. Gourhant and D. Delille, Effects of nutrient and temperature on degradation of petroleum hydrocarbons in contaminated sub- Antarctic soil, Chemosphere, 2005, 58, 1439-1448.

$23 \mathrm{~J}$. Walworth and C. Reynolds, Bioremediation of a petroleum-contaminated cryic soil: effects of phosphorous, nitrogen, and temperature, J. Soil Contam., 2005, 4, 299-310. 